\title{
123.
}

$6 r T .84: 6 r 2 . I$

\section{硝子體 ノ特異性二關スル研究}

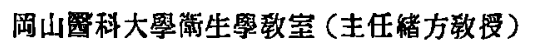

後 藤 義 貞

[昭和 7 年 2 月 $27 \mathrm{H}$ 受稿]

Aus dem Hygienischen Institut der Med. Universität Okayama

(Vorstand: Prof. Dr. M. Ogata).

Beitrag zur Spezifität der Glaskorperantigen.

Von

Yoshisada Gotoh.

Eingegangen am 27. Februır 1932.

Es ist noch kein befriegender Nachweis über Differenzierung zwischen Serüantigen und Glaskzorperantigen erbracht worden, der durch Präzipitin- oder Komplementbindungsreaktion oder weiter durch Anaphylaxie von vielen Autoren studiert wurde. Vor kurzem hat Makino in unserem Institut durch Absorptionsversuch die Differenz zwischen Glaskorper und Serum gefunden. Ich habe mich mit dieser Frage mittels Präzipitinversuch und Komplementbindung oder Anaphylaxieversuch mit Antiglaskorperserum von Kaninchen beschäftigt und konnte mit Sicherheit eine Differenzierung der beiden feststellen. Doch war umgekehrt die Reagierbarkeit des Antiserumpräzipitins auf Serumantigen etwas differenziert, weil dabei der Präzipitintiter auf Glaskörper durch die Ublenhuthmethode $1 / 2$ des Serumantigens, der Präzipitintiter nach Verdünnungsmethode 1/8 zeigt. Durch Absorptionsversuch des Antiglaskőrperserums durch Serumpulver kann man auch wie bei Makino die beiden Antigene unterscheiden, weil nach Absorption mit Serumantigen der Glaskörperantikörper bleibt. Wie schon oben gesagt ist die Unterscheidung zwischen Serum und Glaskororper durch Glaskorperimmunserum unmoglich. Doch ist es wohl möglich, durch Immunisierungsweise spezifische Glaskörperantikorper zu erhalten. Ich habe den Glaskörper des Rindes mit Antirinderserumpräzipitin stark sensibilisiert und den Bodensatz ablaufen lassen. Nach Zentrifugierung habe ich klares Abgussserum bekommen, in dem Glas- 
kơrperaṇtigen erhalten sein mag. Nach wiederholter Digerierung mit Antiglaskőrperimmunserum wurde der Bodensatz, in dem sich wohl auch Glaskorperimmunserum befand, abgesondert und nach Waschung wurde mit diesem Bodensatz das Kaninchen immunisiert. Nach 3 maliger Injektion habe ich ein Immunserum gehabt, das auf Glaskorperantigen 2 mal hơher als auf Serumantigen reagiert. Durçh Komplementbindungsreaktion wurde auch gleiches Resultat erzielt. Leider war bei weiterer Immunisierung mit diesem Bodensatz der Titer für beide Antigene gleich geworden. Deshalb bleibt mein Versuch nur ein Nachweis für die Möglichkeit einer Beschreibung des spezifischen Glaskörperimmunserums. (Attoreferat.)

目次

第 1 章 緒 諭

第 2 章 實驗方法

第 1 節 抗原八製法

第 2 節 免投血清

第 3 節 檢查方法

第 1 愐 沈降反痼

第 2 項 補體結合反應
第 3 項 吸收試驗

第 3 章 抗确子筑免没血清二就テノ賽驗

第 4 草 抗血清免浚血清二颜テノ惯䮦

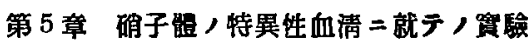

第 6 章 總括，考案

第7章 結 論

文 妝

\section{第 1 草緒論}

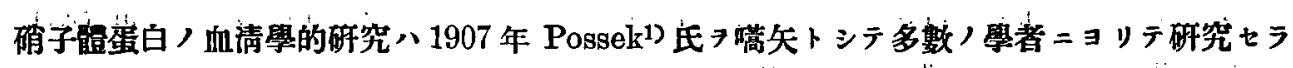

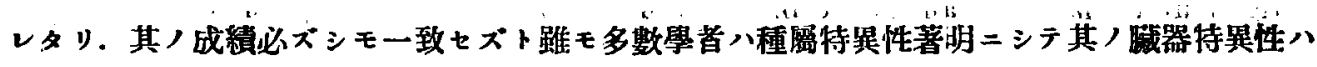

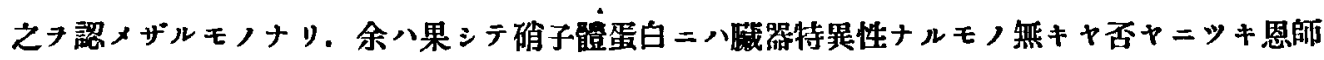

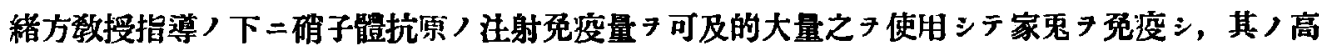

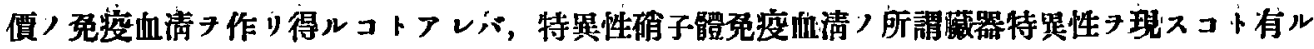
ヤ不ヤタ检索七り。

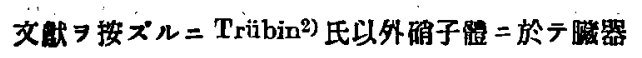
特異性 認メタル者ナシ.

1907 年 Possek 氏八最初牛, 确子體 $\rightarrow$ 無菌的二探

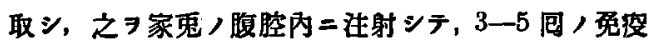

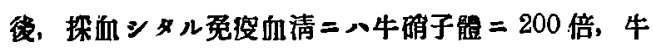

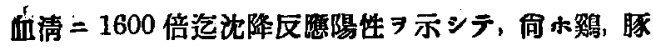

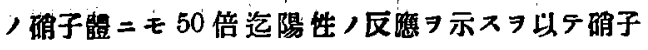

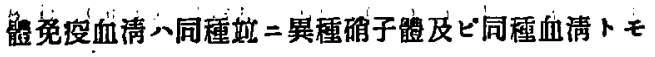

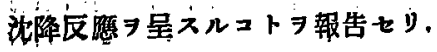

Trübin 氏 1914 年牛确子體二厂海猽习過敏性ト

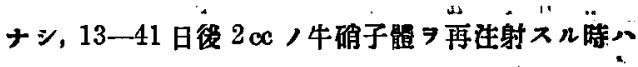

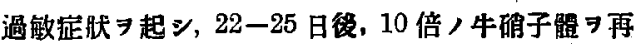
注射シテ 50\% 二過敏症 合, 再注射二際シテ牛确子體二換フルニ緬羊确子罝

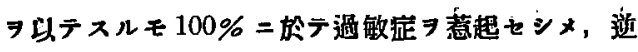

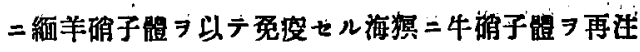

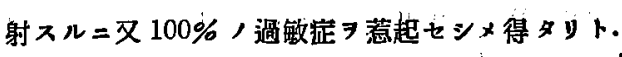
之二反シテ血清始二水晶能 


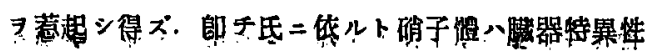
滍キコトヨ報告セリ.

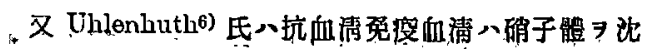
降セシメ得ズト。

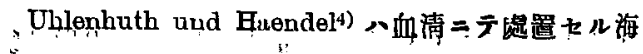

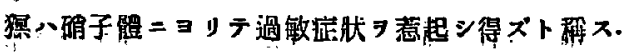

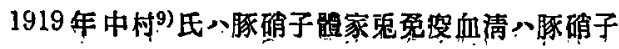

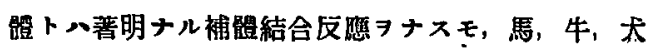

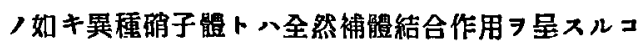
ト㶵シト，而モ種屬特異性著明ナル＝血清トハ反應 全り陰性ナリト云フ.

村上 ${ }^{10)}$ 氏モ亦 1921 年，馬，豚，牛，各确子體二就 キ㭪路結合反㤫

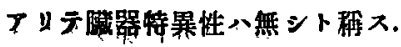

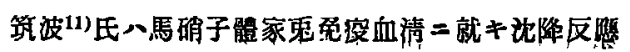

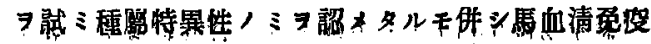

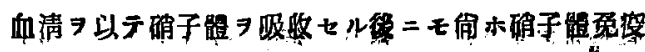
血清ニョリテ沈降スト云フ。

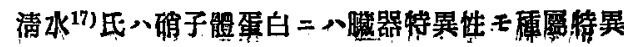

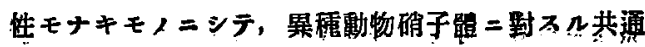
性ワ含有七ズト程ス.

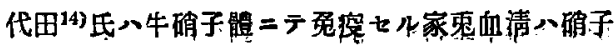

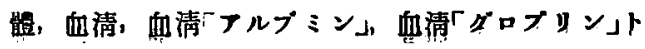

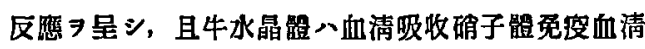
ト陽性二反㗹スト程ス。

1925 年，木村 ${ }^{16)}$ 氏モ之ト同榇ナル事黑 7 報告せ y.

我力゙致室二於テ牧野 ${ }^{13)}$ 氏八确子體，種瓷特異性モ

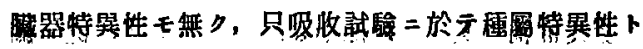

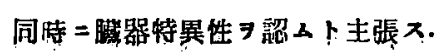

以上ノ如ク硝子體ノ特暴性ハ諸家ニヨリラ砄究セラレタル所ナルモ未ダ確定セルモノナキガ 如 三.

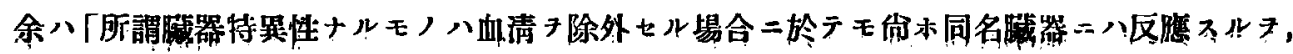

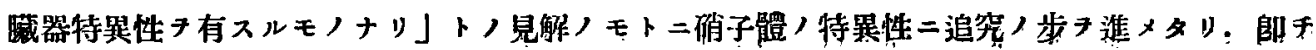

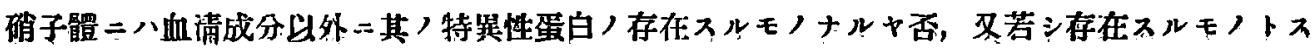

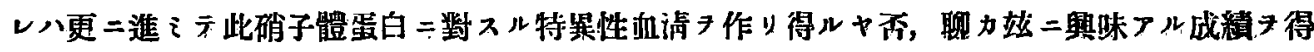
タルタ凶テ其ノ概要ヨ報告セントス。

\section{第 2 章 實 驗 方}

第 1 節执原, 彆法

新鮮ナル眼球ョり得タル确子䯠八牛，䀠，山羊，鵎

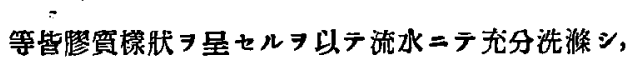

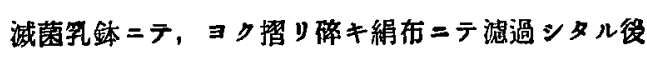
遠心沈降シテ其ノ上清 7 探 リ沈降原トシテ 、其ノ儘

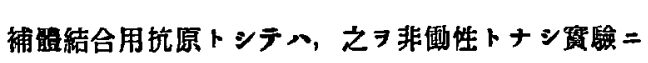
供 .

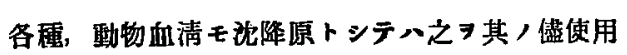

\footnotetext{
シ，補體結合反應ニ在ソテハ非働性トシテ用フ。 吸收抗原トシテハ新鮮ナル血清又八确子體 7 磁器

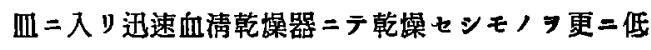

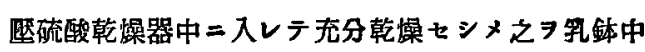
ニテ粉末トナシ吸收原トシテハ其ノ隐嘪验二供ス.

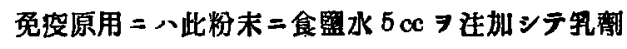
ト䉆シテ用フ。
}

\section{第 2 節 兔疼 血 洼}




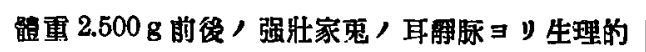

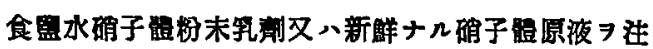
射 $x$.

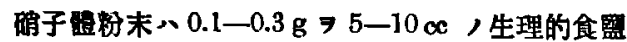

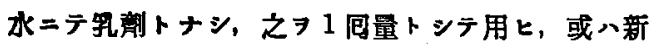

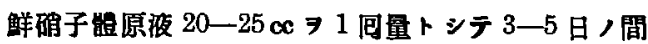

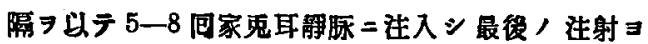

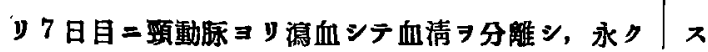

\section{第 3 節 检 查 方 法}

第 1 項 沈 降 反 㦄

（1）Uhlenhuth 氏法

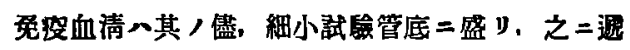

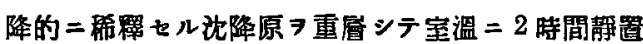

（2）緹方氏稀䆁法

免浸血清 $710 \%$ 海猽生理的食垌水溶液又, $1 \%$

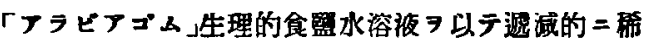

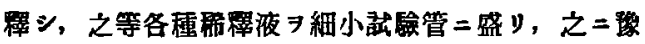

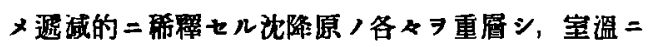

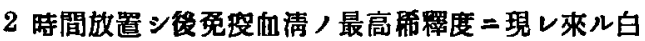

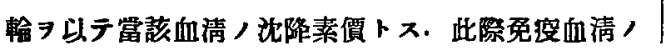

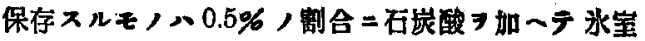
二眝一宽酸二供ス。

血清沉原八新鮮ナルモ，0.5-100 生理的食監水

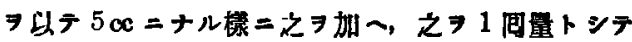

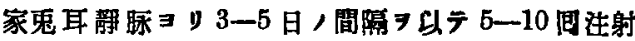

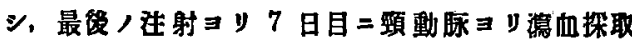

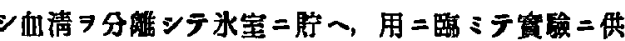
ז.

第 2 項補體結合反應

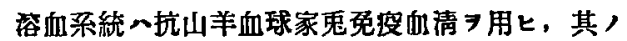
溶血價 2 倍 $\exists$ 使用シ，之ト $2.5 \%$ 山羊血峨浮游液

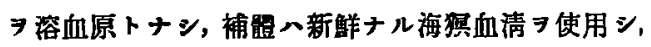
其, 使用, 都度其, 補體價 $\exists$ 測定 三八常二補能價, 1.5 倍量 $习$ 使用セリ.

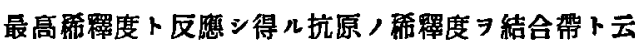

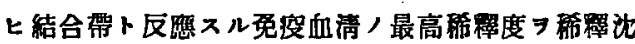
降菜酒ト云フ。

白鐱 15 分間以內 $=$ 現ルル 內二出現スルэ卅 1 時间以內 7 \# 2 時間以内

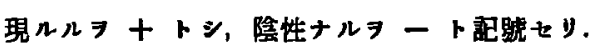

头二叒疫血清及ビ抗原，浴血抑止作用

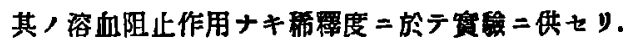

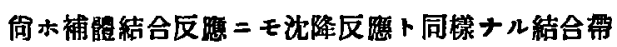
フォ、結合帶二於テ最モ强ク㭪體結合反應 八雄降反應二於ヶルガ如シ.

\section{第 3 項 吸 收 試 驗}

吸收抗原トシテ用ヒタルハ确子體及ビ血清ニシテ

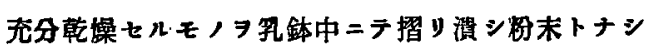
免度血清 $1.0 \propto$ 中二确子䯏或八血清粉末 $70.01 \mathrm{~g}$ ，

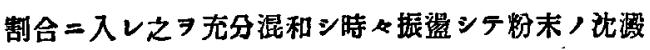

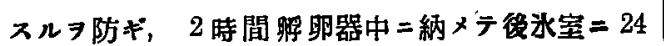

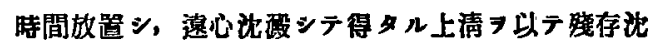

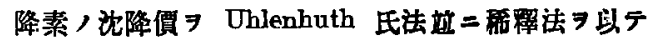

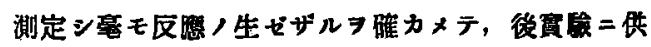
x. 


\section{第 3 草抗硝子體家鬼免疫血清二就テノ實驗}

沈降反熨

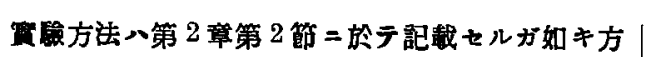

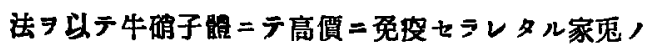

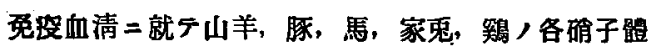

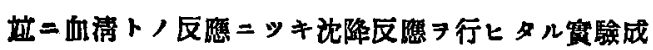
绕入第 1 表ニボルガ如シ.

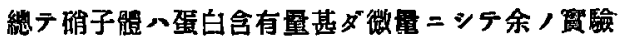

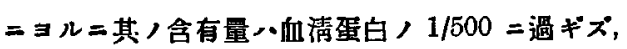
故二以下砣子體原液 7 血清蛋白二換算シテ, 血清 1/500 倍猫釋ニ一致スルモノト記七リ。

第 1 表 抗牛硝子體家束免疫血清，沈降反應 (Nr. 112 家鬼)

\begin{tabular}{|c|c|c|c|c|c|c|c|c|c|c|c|c|c|c|c|c|c|c|c|}
\hline \multirow{2}{*}{ 抗原種剧 } & \multicolumn{8}{|c|}{ Uhlenhuth 氏法 } & \multirow{2}{*}{$\begin{array}{l}\text { 反 } \\
\text { 隹 } \\
\text { 度 }\end{array}$} & \multirow{2}{*}{ 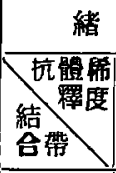 } & \multicolumn{2}{|c|}{ 方 } & 氏 & 㻩 & \multicolumn{2}{|c|}{ 䆁 } & \multicolumn{2}{|c|}{ 法 } & \multirow{2}{*}{$\begin{array}{l}\text { 反 } \\
\text { 㮣 } \\
\text { 度 }\end{array}$} \\
\hline & $\begin{array}{l}8 \\
8 \\
- \\
\end{array}$ & $\begin{array}{l}8 \\
8 \\
\\
\\
-. \\
\end{array}$ & 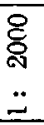 & 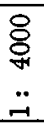 & \begin{tabular}{|c|}
8 \\
8 \\
\\
\end{tabular} & \begin{tabular}{l}
8 \\
8 \\
\hdashline \\
\hdashline
\end{tabular} & 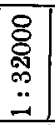 & \begin{tabular}{l}
8 \\
8 \\
8 \\
\multirow{8}{*}{} \\
$\ddot{-}$ \\
\end{tabular} & & & $\begin{array}{l}n \\
\ddot{\sim}\end{array}$ & $\left|\begin{array}{c}0 \\
\ddot{1} \\
\ddot{-}\end{array}\right|$ & $\begin{array}{l}\text { न } \\
\ddot{\sim} \\
\ddot{\sim}\end{array}$ & $\begin{array}{l}\text { 옥 } \\
\ddot{-} \\
-\end{array}$ & $\begin{array}{l}\triangleright \\
\ddot{न} \\
.\end{array}$ & $\begin{array}{c}8 \\
0 \\
\because \\
\because-1\end{array}$ & 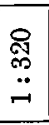 & $\begin{array}{l}\text { 윰 } \\
\ddot{0} \\
-1\end{array}$ & \\
\hline 牛 硝子體 & 册 & 册 & 册 & 册 & 曲 & H & $H$ & - & $100 \%$ & $1: 2000$ & 册 & 曲 & 曲 & 曲 & $\mathrm{H}$ & $H$ & $H$ & - & $100 \%$ \\
\hline 山羊 & 册 & 册 & 册 & $\mathrm{HH}$ & 世 & $H$ & - & - & $50 \%$ & $1: 2000$ & 册 & 册 & H & H & $H$ & - & - & - & $25 \%$ \\
\hline 䀠 & 世 & 世 & $H$ & - & - & - & - & - & $6 \%$ & $1: 1000$ & $\mathrm{HH}$ & $H$ & - & - & & & & & $6 \%$ \\
\hline 馬 & $\mathrm{HH}$ & + & - & - & - & - & - & - & $3 \%$ & $1: 500$ & 世 & \pm & - & & & & & & $3 \%$ \\
\hline 哭鳥 & - & - & - & & & & & & 0 & 0 & - & - & - & & & & & & 0 \\
\hline 家患 & - & - & - & & & & & & 0 & 0 & - & - & - & & & & & & 0 \\
\hline 牛 血 & HAt & 册 & 册 & 册 & H & H & $H$ & - & $100 \%$ & $1: 2000$ & 册 & 册 & 曲 & 册 & IH & $H$ & + & - & $100 \%$ \\
\hline 山羊 & 册 & 册 & 曲 & HH & H & $H$ & - & & $50 \%$ & $1: 2000$ & H\# & HA & $H$ & $H$ & + & - & - & & $25 \%$ \\
\hline 豚 & HI & $H$ & + & - & & & & & $6 \%$ & $1: 250$ & HI & $H$ & \pm & - & - & & & & $6 \%$ \\
\hline 馬 & $H$ & - & - & - & & & & & $1.5 \%$ & $1: 250$ & H & \pm & - & - & - & & & & $3 \%$ \\
\hline 家鬼 & - & - & - & & & & & & 0 & 0 & - & - & - & -1 & & & & & 0 \\
\hline 䊿島 & - & - & - & & & & & & 0 & 0 & - & - & - & - & & & & & 0 \\
\hline
\end{tabular}

第 1 表二望テ示セルガ如ク Dhlenhuth 氏沈降反㮣

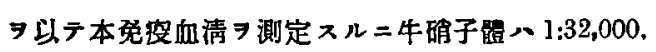

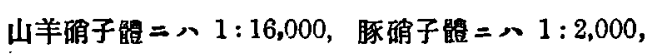

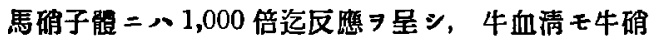
子鼠卜同栚 $=1: 32,000$ 迄反應 7 呈シ，山羊血清、 $1: 16,000$, 豚血清 $・ 2,000$ 倍，馬血清、 500 倍迄反

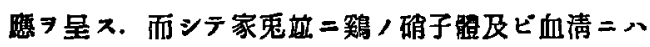
反既セズ.

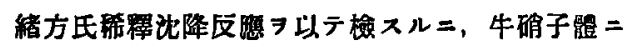
到シ, 結合带 2,000 倍, 稀䆁㵋 320 倍迄反隼 ス, 山

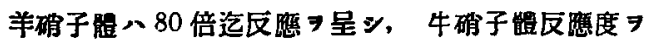

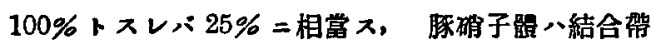
$1: 1,000$ ニシテ 10 倍迄反應シ $6 \%$ ，類瓷反暨 7

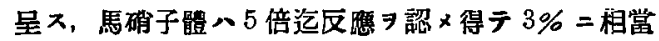
ז.

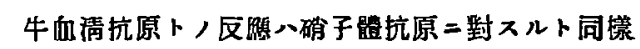

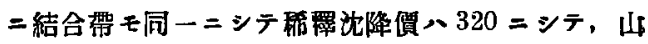
羊血清抗原八結合带 $1: 2000$, 沈降素潧八8 0 倍, 豚 血清八結合带 $1: 250$ ニシテ 10 倍迄反㮣 血清抗原八結合帶 $1: 250=シ テ 5$ 倍迄反留

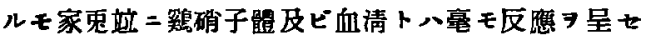
ズ.

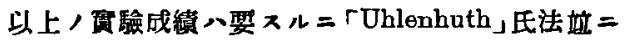

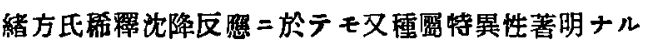

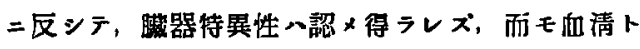
，區別モ困難ナり。 


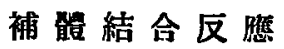

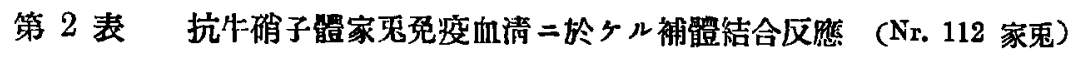

\begin{tabular}{|c|c|c|c|c|c|c|c|c|c|c|c|c|}
\hline 抗原種別 & & & 䆁 度 & $\ddot{ت}$ & $\begin{array}{l}\stackrel{ }{\ominus} \\
\ddot{-}\end{array}$ & $\begin{array}{l}\stackrel{8}{ } \\
\ddot{\pi}\end{array}$ & $\begin{array}{l}\text { 웅 } \\
\ddot{\sim}\end{array}$ & $\begin{array}{l}\dot{\infty} \\
\ddot{\sim}\end{array}$ & 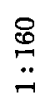 & 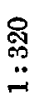 & $\begin{array}{l}\text { 윰 } \\
\stackrel{-}{-1}\end{array}$ & $\begin{array}{l}\text { 鷹 } \\
\text { 度 }\end{array}$ \\
\hline 牛 硝 & 子 & 體 & $1: 4000$ & + & + & + & + & + & + & - & - & $100 \%$ \\
\hline 山 羊 & $\Rightarrow$ & & $1: 2000$ & + & + & + & + & - & - & - & - & $25 \%$ \\
\hline 豚 & $\Rightarrow$ & & $1: 1000$ & + & - & - & & & & & & $3 \%$ \\
\hline 馬 & " & & $1: 500$ & + & - & - & & & & & & $3 \%$ \\
\hline 家 兔 & $"$ & & 0 & - & - & - & & & & & & 0 \\
\hline 羿鳥 & " & & 0 & - & - & - & & & & & & 0 \\
\hline 牛 & & 清 & $1: 4000$ & + & + & + & + & + & + & - & - & $100 \%$ \\
\hline 山 羊 & " & & $1: 2000$ & + & + & + & \pm & - & - & - & - & $12.5 \%$ \\
\hline 豚 & $=$ & & ]$: 250$ & + & \pm & - & - & & & & & $3 \%$ \\
\hline 馬 & " & & $1: 250$ & + & - & - & - & & & & & $3 \%$ \\
\hline 家 鬼 & $\Rightarrow$ & & 0 & - & - & - & - & & & & & 0 \\
\hline 鵄 & " & & 0 & - & - & - & - & & & & & 0 \\
\hline
\end{tabular}

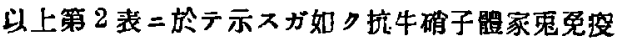

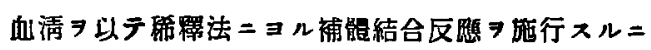

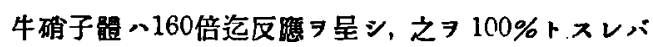
山半确子能八 $25 \%$ ，豚，馬，硝子㖘八 $3 \%$ ニシテ，家

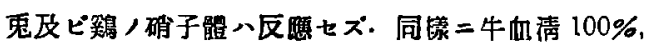
山羊血清 $12 \%$ ，䀠，馬血清 $3 \%$ /反鳃度 $\ni$ 示ス。

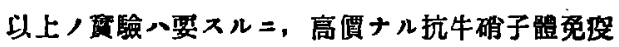

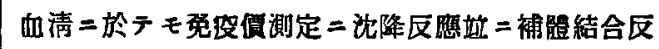

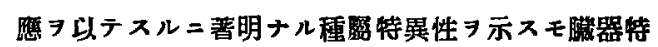

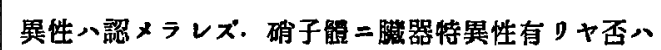

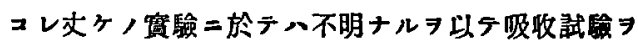
以テ始メテ血清ト區剧シ得ベ\%（後章急炤）

抗牛硝子體家鬼免疫血清ト牛, 他晠器卜弓關係

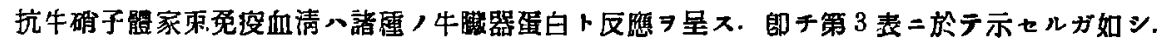

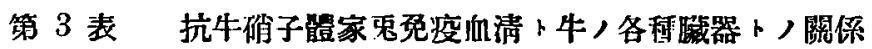
沈降反隼 (Nr. 112 家孯)

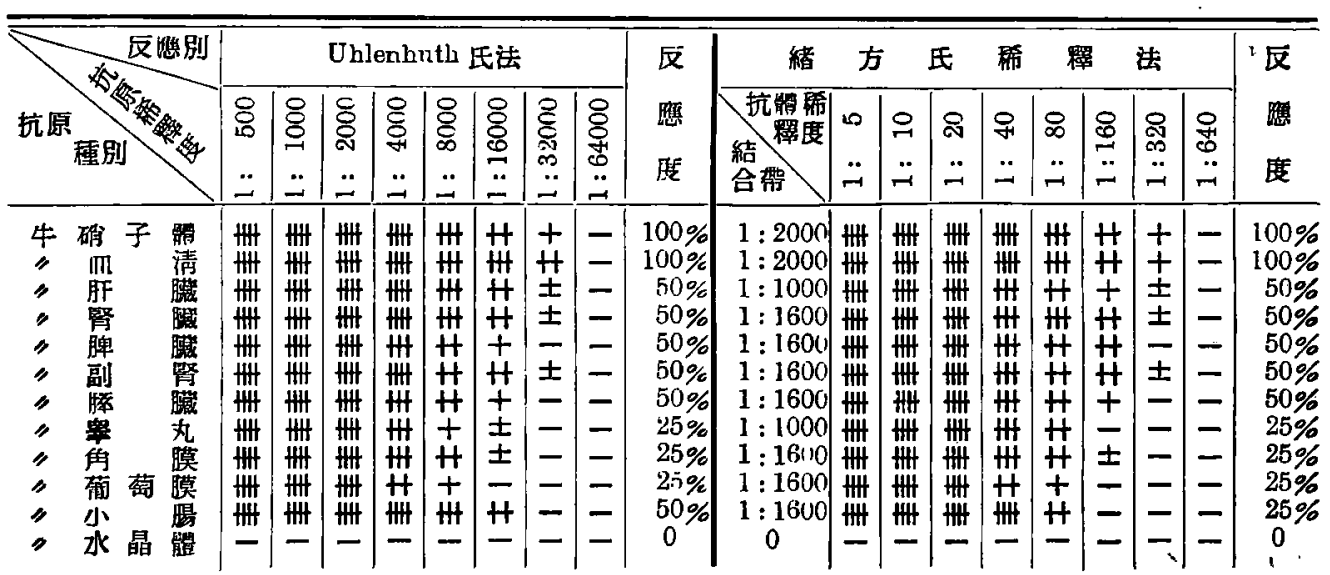




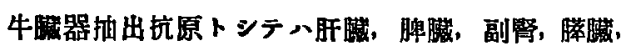

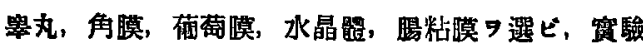
方法第 2 章第 1 節 1 如》調製シ之习抗原トンテ沈降 反應 $\rightarrow$ 行 $=$ 第 3 表ノ如キ結果 $\Rightarrow$ 得タリ.

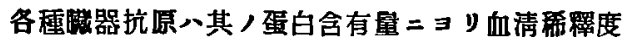

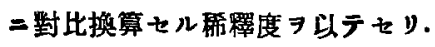

第 3 表, 成綪 7 見 $=$ Uhlenhnth氏法二於テ 一血

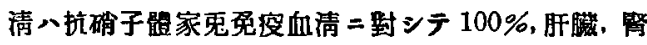

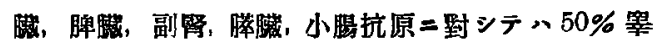
丸，角膜及ビ蔽蒛膜抗原二到シテハ25\%，反應度 7 示ス.

緒方氏抗體稀釋法 7 以テスルモ大略Ublenhnth氏 法二於ヶルガ如キ反磼度

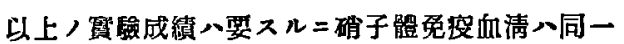

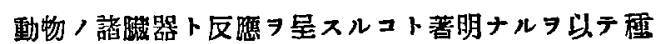
屬特異性モ亦著明ナリ。

吸收試驗二就テ

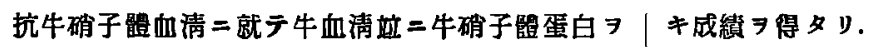

以テ眼收試驗 7 施行スル二次，第 4 表二於ヶルガ如

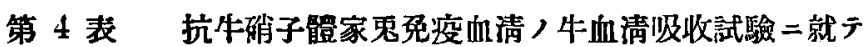

沈降 反 應 (Nr. 112 家鬼)

\begin{tabular}{|c|c|c|c|c|c|c|c|c|c|c|c|c|c|c|c|c|c|c|c|}
\hline \multirow{2}{*}{ 抗原碃剧 } & \multicolumn{8}{|c|}{ Chlenhuth 氏法 } & \multirow{2}{*}{$\begin{array}{l}\text { 反 } \\
\text { 應 } \\
\text { 度 }\end{array}$} & \multirow{2}{*}{ 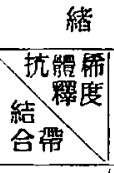 } & \multicolumn{2}{|c|}{ 方 } & 氏 & \multicolumn{3}{|c|}{ 㭴 } & \multicolumn{2}{|c|}{ 法 } & \multirow{2}{*}{$\begin{array}{l}\text { 反 } \\
\text { 䐆 } \\
\text { 度 }\end{array}$} \\
\hline & $\begin{array}{l}8 \\
\ddot{0} \\
\end{array}$ & $\begin{array}{l}8 \\
8 \\
-1 \\
\end{array}$ & \begin{tabular}{l}
8 \\
8 \\
8 \\
\hdashline \\
\end{tabular} & $\begin{array}{l}8 \\
\stackrel{8}{+} \\
\ddot{-} \\
\end{array}$ & $\begin{array}{l}8 \\
\varnothing \\
\infty \\
. .\end{array}$ & \begin{tabular}{l}
8 \\
8 \\
8 \\
\hdashline \\
\hdashline
\end{tabular} & 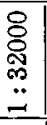 & \begin{tabular}{l}
8 \\
8 \\
8 \\
$\vdots$ \\
\hdashline \\
-
\end{tabular} & & & $\begin{array}{l}\boldsymbol{N} \\
\ddot{\sim}\end{array}$ & $\begin{array}{l}H \\
\ddot{z}\end{array}$ & $\begin{array}{l}\infty \\
\ddot{-}\end{array}$ & $\begin{array}{l}0 \\
-1 \\
\ddot{-}\end{array}$ & $\begin{array}{l}\tilde{\infty} \\
\ddot{\sim}\end{array}$ & $\begin{array}{l}\overrightarrow{0} \\
\because \\
-\end{array}$ & \begin{tabular}{l}
$\infty$ \\
\multirow{2}{*}{} \\
$\ddot{\sim}$ \\
\end{tabular} & 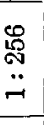 & \\
\hline 牛 硝 子 奛 & 册 & 冊 & $H$ & $H$ & + & - & - & - & $100 \%$ & $1: 1000$ & 曲 & H & $\mathrm{Ht}$ & $H$ & $H$ & -1 & - & - & $100 \%$ \\
\hline 山羊 & 册 & H & $H$ & + & - & - & - & - & $50 \%$ & $1: 1000$ & W & $\mathrm{HH}$ & $H$ & + & - & - & - & - & $50 \%$ \\
\hline 睆 & H & $H$ & - & - & - & - & - & - & $12.5 \%$ & $1: 500$ & H & $\rightarrow$ & -1 & - & & & & & $6 \%$ \\
\hline 馬 & $H$ & - & - & - & - & - & - & - & $6 \%$ & $1: 500$ & $H$ & - & - & - & & & & & $6 \%$ \\
\hline 家鬼 & - & - & - & - & - & - & - & - & 0 & 0 & - & - & - & - & & & & & 0 \\
\hline 䍈 & - & - & - & - & - & - & - & - & 0 & 0 & - & - & - & - & & & & & 0 \\
\hline 牛 血 清 & - & - & - & - & - & - & - & - & 0 & 0 & - & - & - & - & & & & & 0 \\
\hline 山羊 & - & - & - & - & - & - & - & - & 0 & 0 & - & - & - & - & & & & & 0 \\
\hline 係 & - & - & - & - & - & - & - & - & 0 & 0 & - & - & - & - & & & & & 0 \\
\hline 馬 & - & - & - & - & - & - & - & - & 0 & 0 & - & - & - & - & & & & & 0 \\
\hline 家鬼 & - & - & - & - & - & - & - & - & 0 & 0 & - & - & - & - & & & & & 0 \\
\hline 䊿鼠 & - & - & - & - & - & - & - & - & 0 & 0 & - & - & - & - & & & & & 0 \\
\hline
\end{tabular}

其，惯验方法、第 2 章第 3 節第 3 項ニテ記セルガ

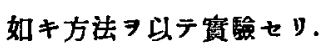

即于第 4 表心牛血清粉末 7 以テ，吸收試驗成縝二

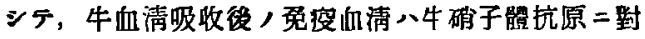
シテ Uhlenhuth 氏法二依レパ 8,000 倍反應シ，山羊

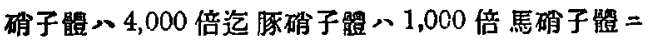

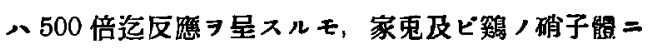
ハ之ニ反シテ喜モ反愳ヨ呈スルコトナシ.
又血清抗原二暍シテハ, 牛血声, 以下山羊，豚， 馬ノ各血清抗原二跮シテハ最早反㮣ヨ呈スルコトナ シ.

之ヨ緒方氏稀濢法二於テ測定スルニ，牛硝子體二

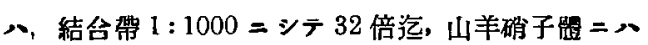

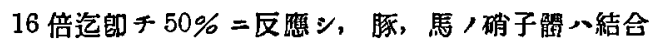

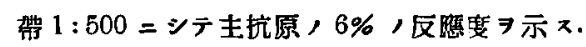

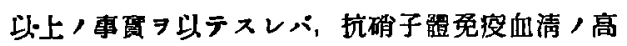




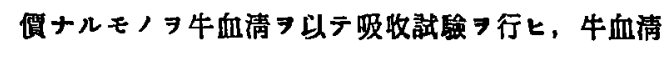

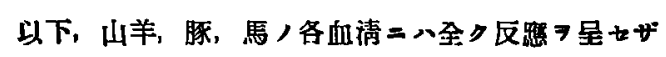

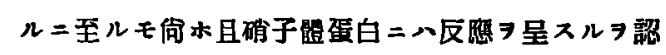
入得々y.

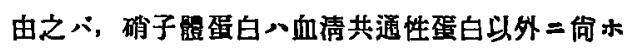
硝子繶獨特ノ蛋白, 存在 x.

此際牛血清吸收誈驗ニョッ著明ナル沈降素，減少

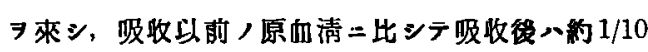
，沈降素 7 示ス $=$ 止マリ，即千約 $9 / 10 ，$ 沈降素隇 少 $\Rightarrow$ 示ス $\Rightarrow$ 以ラ硝子能督白二八多量，伹清共通成分
存在スルコトワモ推察スルニ難カラズ. 、.

尚木牛砣子能免没血清 9 牛硝子能粉末

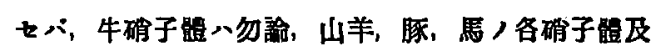
ピ牛，山半，睆，馬/血清成分トモ全然反碓 7 呈セ ザルニ至レリ。

此宽驗成績表八陰性ナル 向ホ牛血清成分吸收後, 殘存沈降菜ニッキ, 牛 各種脿器抗原卜，反㮣

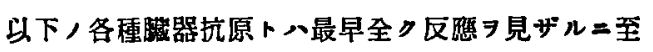
ᄂv.

師于第 5 表 /如シ.

第 5 表 抗牛酳子體家鬼免疫血清, 牛血清吸收後, 沈降反憵

(Nr. 112 家鬼)

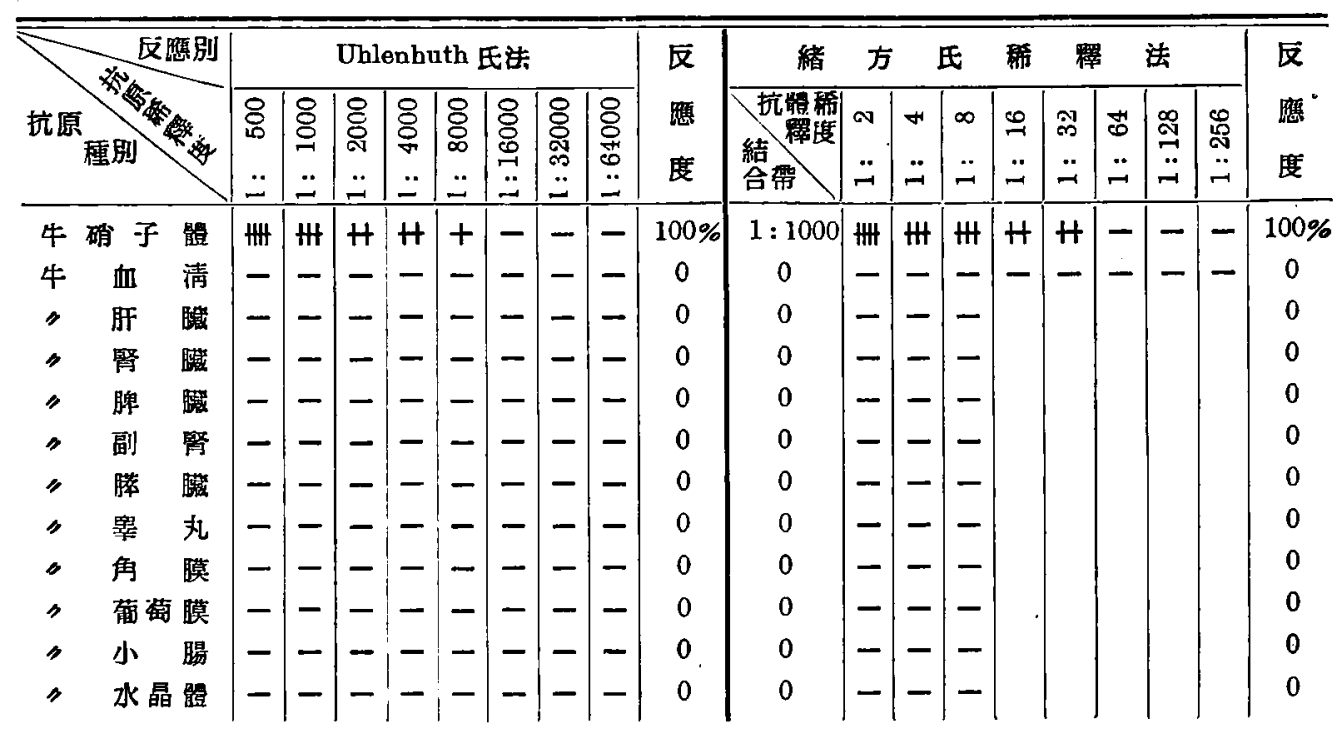

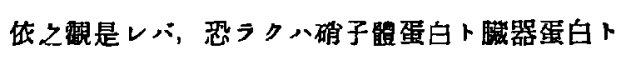

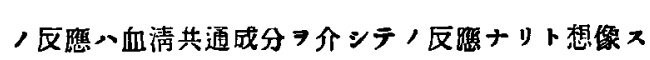
ルン難カラズ.
是レ牧野 ${ }^{13)}$ 氏，苗硻ト一致スル所ニシテ同氏七亦

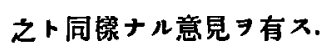

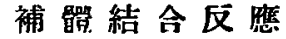

牛血清成分吸收後，殘存沈降素二就キ補能結合反 第 6 表ノ成績 $\exists$ 得タリ。 留 7 行フニ，余八免段血清へ之 4 倍ヨリ稀釋ンテ。 


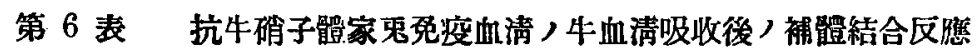

(Nr. 112 家兔)

\begin{tabular}{|c|c|c|c|c|c|c|c|c|c|c|c|c|c|}
\hline \multicolumn{5}{|c|}{ 抗原種別 } & $\begin{array}{l}\boldsymbol{N} \\
\ddot{\sim}\end{array}$ & $\begin{array}{l}\text { H } \\
\ddot{\pi}\end{array}$ & $\begin{array}{l}\infty \\
\ddot{\pi}\end{array}$ & $\begin{array}{l}\stackrel{0}{=} \\
\ddot{\pi}\end{array}$ & $\begin{array}{l}\mathscr{\omega} \\
\ddot{\sim}\end{array}$ & $\begin{array}{l}\text { む } \\
\ddot{\sim}\end{array}$ & $\begin{array}{l}\stackrel{\infty}{*} \\
\underset{\sim}{*}\end{array}$ & $\begin{array}{l}\text { 怘 } \\
\stackrel{-}{\pi}\end{array}$ & 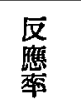 \\
\hline 牛 & 确 & 子 & 體 & $1: 2000$ & 1 & + & + & + & \pm & - & - & - & $100 \%$ \\
\hline 山 & 羊 & $"$ & & $1: 1000$ & $/$ & + & + & \pm & - & - & - & - & $50 \%$ \\
\hline 豚 & & $"$ & & 0 & I & - & - & - & - & - & - & - & 0 \\
\hline 馬 & & $\Rightarrow$ & & 0 & $/$ & - & - & - & - & - & - & - & 0 \\
\hline 家 & 鬼 & $"$ & & 0 & 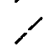 & - & - & - & - & - & - & - & 0 \\
\hline 娭鳥 & & $"$ & & 0 & I & - & - & - & - & - & - & - & 0 \\
\hline 牛 & $\mathbb{t}$ & & 淸 & 0 & 1 & - & - & - & - & - & - & - & 0 \\
\hline 山 & 羊 & 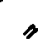 & & 0 & 1 & - & - & - & - & - & - & - & 0 \\
\hline 豚 & & $\Rightarrow$ & & 0 & 1 & - & - & - & - & - & - & - & 0 \\
\hline 馬 & & $"$ & & 0 & / & - & - & - & - & - & - & - & 0 \\
\hline 家 & 鬼 & 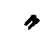 & & 0 & I & - & - & - & - & - & - & - & 0 \\
\hline 鵄 & & $"$ & & 0 & Y & - & - & - & - & - & - & - & 0 \\
\hline
\end{tabular}

師チ箱睪法 7 以テスル 带 $1: 2,000$ =シテ $32( \pm)$ 迄補體 結合シ，山羊硝子

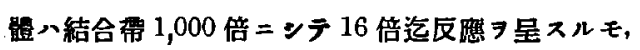

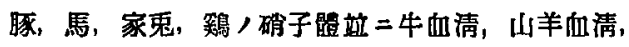
以下ノ血清二ハ毫モ反隼セズ.

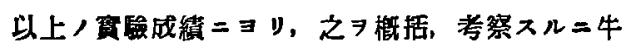
硝子體ノ大空 9 而モ頻回家鬼

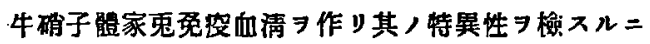
血清，吸收試筑シ施行セザル上前，免没血清ニ於テ

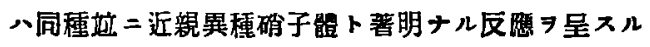

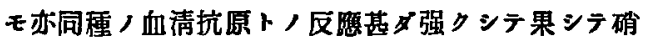
子體蛋白ニョリテカク反應 $、$ 呈スルヤ、又八血清成
分ニョリテ反㮣 ヨ呈スルモノナルヤ不明ナルョ以テ 必ズ吸收試酹 果二於テモ亦硝子體蛋白中二八多量，血清成分共通 蛋白/存在スルコトラ証メ得タリ.

即于血清吸收陚驗二於テ殆ド大部分，抗體 7 消失

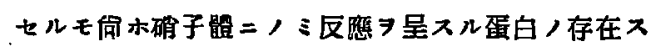
ルョ侸明シ得タリ. 而シテ此残存抗體八血清成分二

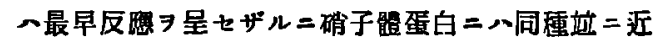

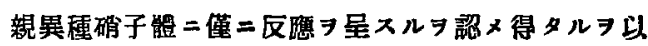
テ硝子體二モ向清成分以外二特異, 硝子體蛋白/存 在スル事贯 $\ni$ 知り得タリ. 余八更二此閶䋆 7 確證七

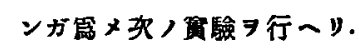

\section{第 4 章 抗牛血清家鬼兔疫血清二就テノ實驗}

家鬼 7 牛血清 7 以テ頻四免没ッ, 就中其, 高價ナ

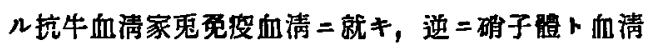

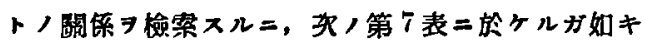
成績 $\boldsymbol{7}$ 得 $タ$.

當該高價抗牛血清家兔免滔血清入牛血清抗原二到 シテハUhlenhnth 法ニテハ1:50,000, 緒方氏法 7
以テスレハ，結合帶 $1: 1,000=シ テ$ 其, 稀釋沈降

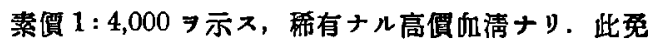
受血消二對シテ牛硝子體 $1: 32,000$, 緒方氏稀䆁法 7 以テスレパ,結合帶 $1: 500$

桸罳僄 $1: 1,000 \Rightarrow$ 示ス.

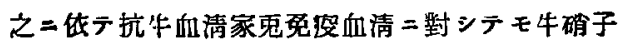




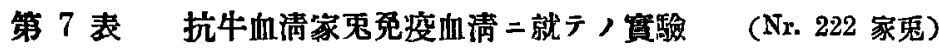

\begin{tabular}{|c|c|c|c|c|c|c|c|c|c|c|c|c|c|}
\hline 吸 收 刷 & 抗原種別 & 「ウ」民法 & $\begin{array}{l}\text { 抗䯣 } \\
\text { 結合带度 }\end{array}$ & $\begin{array}{l}- \\
\ddot{ت}\end{array}$ & $\ddot{\sim}$ & $\begin{array}{l}\stackrel{8}{0} \\
\ddot{\sim}\end{array}$ & $\begin{array}{l}\stackrel{\mathscr{N}}{\mathrm{N}} \\
\ddot{\sim}\end{array}$ & $\begin{array}{l}8 . \\
. \\
\ddot{\sim}\end{array}$ & $\begin{array}{l}\stackrel{8}{o} \\
\ddot{r}\end{array}$ & 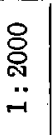 & \begin{tabular}{l}
8 \\
\hdashline \\
$\vdots$ \\
$\because$ \\
\end{tabular} & $\begin{array}{l}\stackrel{8}{8} \\
\vdots \\
\ddot{\pi}\end{array}$ & $\begin{array}{l}\text { 反. } \\
\text { 雔: } \\
\text { 率 }\end{array}$ \\
\hline \multirow{2}{*}{ 吸 叹 首 } & 牛血 清 & $1: 50000$ & $\begin{array}{l}1: 500 \\
1: 1000 \\
1: 2500\end{array}$ & \begin{tabular}{l|} 
mt \\
册 \\
mt
\end{tabular} & $\begin{array}{l}\text { 册 } \\
\text { 册 } \\
\text { 冊 }\end{array}$ & 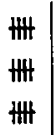 & \begin{tabular}{l|} 
m \\
m \\
mf
\end{tabular} & \begin{tabular}{l|} 
mI \\
mf \\
mt
\end{tabular} & $\begin{array}{l}\mathrm{H} \\
\mathrm{H} \\
\mathrm{H}\end{array}$ & $\begin{array}{l}H \\
+ \\
H\end{array}$ & $\begin{array}{l}+ \\
H \\
-\end{array}$ & $\begin{array}{l}- \\
- \\
-\end{array}$ & $100 \%$ \\
\hline & 牛硙子體 & $1: 32000$ & $\begin{array}{l}1: 500 \\
1: 1000 \\
1: 2000\end{array}$ & $\begin{array}{l}\text { HWh } \\
\mathrm{mt} \\
\mathrm{m}\end{array}$ & $\begin{array}{l}\text { 册 } \\
\text { 册 } \\
\text { 册 }\end{array}$ & \begin{tabular}{l|}
$+\ldots t$ \\
m \\
m
\end{tabular} & $\begin{array}{l}\mathrm{WI} \\
\mathrm{WH} \\
\mathrm{Wt}\end{array}$ & $\begin{array}{l}+ \\
H \\
H\end{array}$ & $\begin{array}{l}H \\
+ \\
+\end{array}$ & $\begin{array}{l}- \\
- \\
-\end{array}$ & $\begin{array}{l}- \\
- \\
-\end{array}$ & $\begin{array}{l}- \\
- \\
-\end{array}$ & $25 \%$ \\
\hline \multirow{2}{*}{$\begin{array}{l}\text { 牛硝子體 } 7 \\
\text { 以于吸收後 }\end{array}$} & 牛血 淸 & $1: 50000$ & $\begin{array}{l}1: 500 \\
1: 1000 \\
1: 2500\end{array}$ & 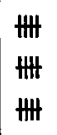 & $\begin{array}{l}\text { WH } \\
\text { WH } \\
\text { WH }\end{array}$ & $\begin{array}{l}\text { WH } \\
\text { HW } \\
\mathrm{W}\end{array}$ & $\begin{array}{l}\text { H } \\
\text { W } \\
H\end{array}$ & $\begin{array}{l}H \\
H \\
+\end{array}$ & $\begin{array}{l}+ \\
+ \\
-\end{array}$ & $\begin{array}{l}- \\
- \\
-\end{array}$ & $\begin{array}{l}- \\
- \\
-\end{array}$ & $\begin{array}{l}- \\
- \\
-\end{array}$ & $25 \%$ \\
\hline & 牛硝子顝 & 0 & $\begin{array}{l}1: 500 \\
1: 1000 \\
1: 2000\end{array}$ & $\begin{array}{l}- \\
- \\
-\end{array}$ & $\begin{array}{l}- \\
- \\
-\end{array}$ & $\begin{array}{l}- \\
- \\
-\end{array}$ & \begin{tabular}{l|}
- \\
- \\
-
\end{tabular} & $\begin{array}{l}- \\
- \\
-\end{array}$ & $\begin{array}{l}- \\
- \\
-\end{array}$ & $\begin{array}{l}- \\
- \\
-\end{array}$ & $\begin{array}{l}- \\
- \\
-\end{array}$ & $\begin{array}{l}- \\
- \\
-\end{array}$ & $0 \%$ \\
\hline
\end{tabular}

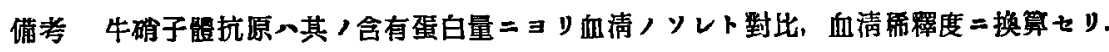

嵁八甚ダ良好ナル反應

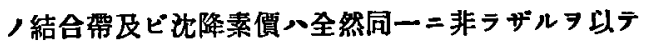
硝子體蛋白八全ク血清蛋白卜同一無ニナルモノト 云ヒ難シ．即チ假二同一ナルモノトスレバ其ノ結合 帶ニ於テモ沈降素㵋二於テモ全然同一ナラザルごカ

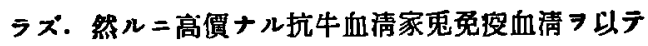

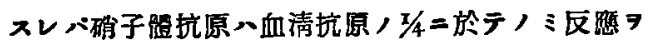
星スルョ見タリ。

故二硝子體心血清共通成分 $ヨ$ 多屋二含有スルモ未 ダ全然同一ナルモノニ非ラザルモノナルペシ.

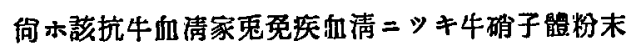

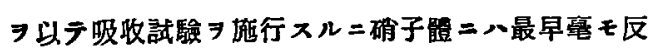

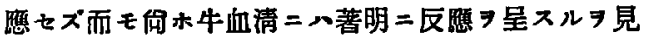
S) 1 .

依之睍是バ琶ラク硝子體蛋白一其ノ大部分血清共 通性蛋白 存在スルモノナルベシ.

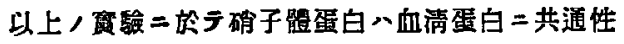

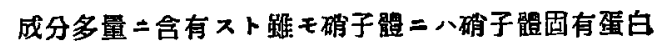
人存在 $\exists$ 認諳シ得 $¥$.

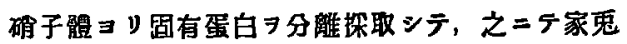

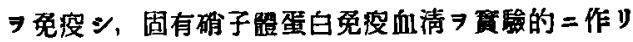

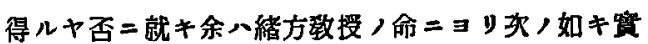
䛗

\section{第 5 章 硝子體蛋白特異性家鬼免疫血清二就テノ實驗}

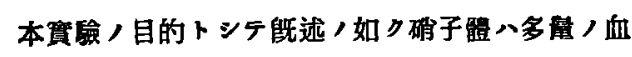
清成分卜且磎子喵固有蛋白ノ共存スルモノニシテ，

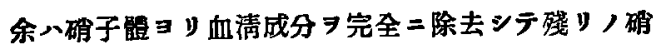
子體固有蛋白
毫モ血清二反應スルコトナク，硝子體蛋白二ノミ反 應 下記裁, 窝驗 ᄌ. 
實 驗 第 1

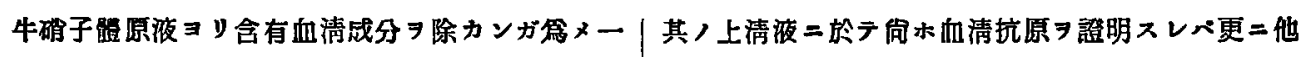

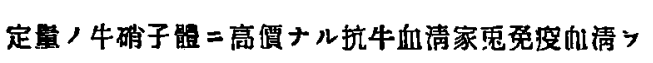
，高侻抗牛血清家鬼蛋没血清 7 以テ血清成分 7 出來

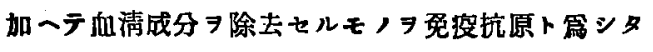
リ。即于余ハ新鮮ナル牛硝子䯏原假 $5 \mathrm{cc}=$ 對シ高價 ナル抗牛血清家鬼免受血清 ( $「 U 」$ 氏法. $1: 10,000$ 稀

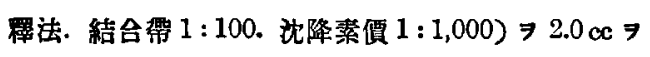
之二注加シ，充壬摚汼注和シテ, 2 时間船卵器中二 置キ後 24 時間水室二保存シ置キ,之习遠心沈降シテ ル丈ケ吸收除去スル二努メ，完全二血清成分 7 吸收 除去スルラ以テ理想トスルモノナレド微量ノ血清 成分，存在八宣祭上此 $カ$ 得ザルモノナリ.

以上，如キ方法二テ血清成分 7 可及的完全二除カ

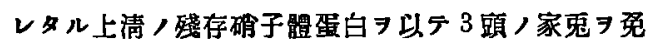
没セり.之ョA. gruppeト假稱セり。

貿 驗 第 2

次二上还，血清成分除去後，上清 =更二我㵋ナル 牛硝子能家鬼免没血清(結合带 $1: 2,000$. 稀擇沈降 素㵋 $1: 200-320) ７$ 硝子體上清 $5 c=$ 對

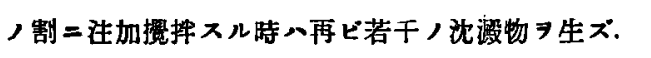

\section{賽 䮔 第 3}

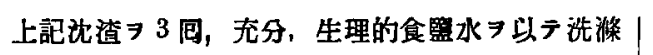

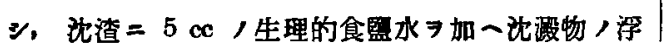

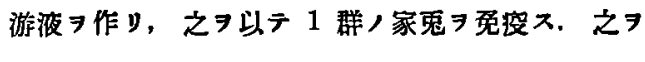
C. gruppe 卜假稱ス.

貫 䮲 第 4

新鮮ナル牛硝子䯏原夜 $5 \mathrm{cc}=$ 對三抗牛硝子䯏家兔

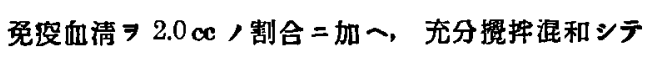

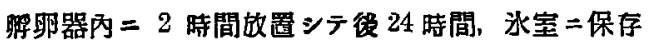
シ, 遠心沈降シタ儿沈澱物 $=3$ 回生理的食監水 $\Rightarrow$ 以

獀 噞 第 5

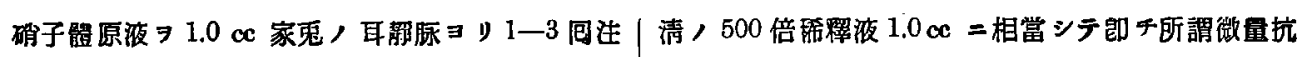
射シテ, 其, 沈㹣素逢生狀態 7 榆索セり。蓋シ硝子

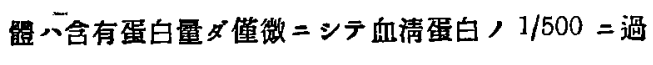

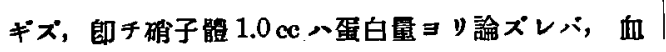
原注射二相當スベキモノナリ. 此免疫家鬼 1 群 $\Rightarrow$ E. gruppe 卜假㛵 $x$. 


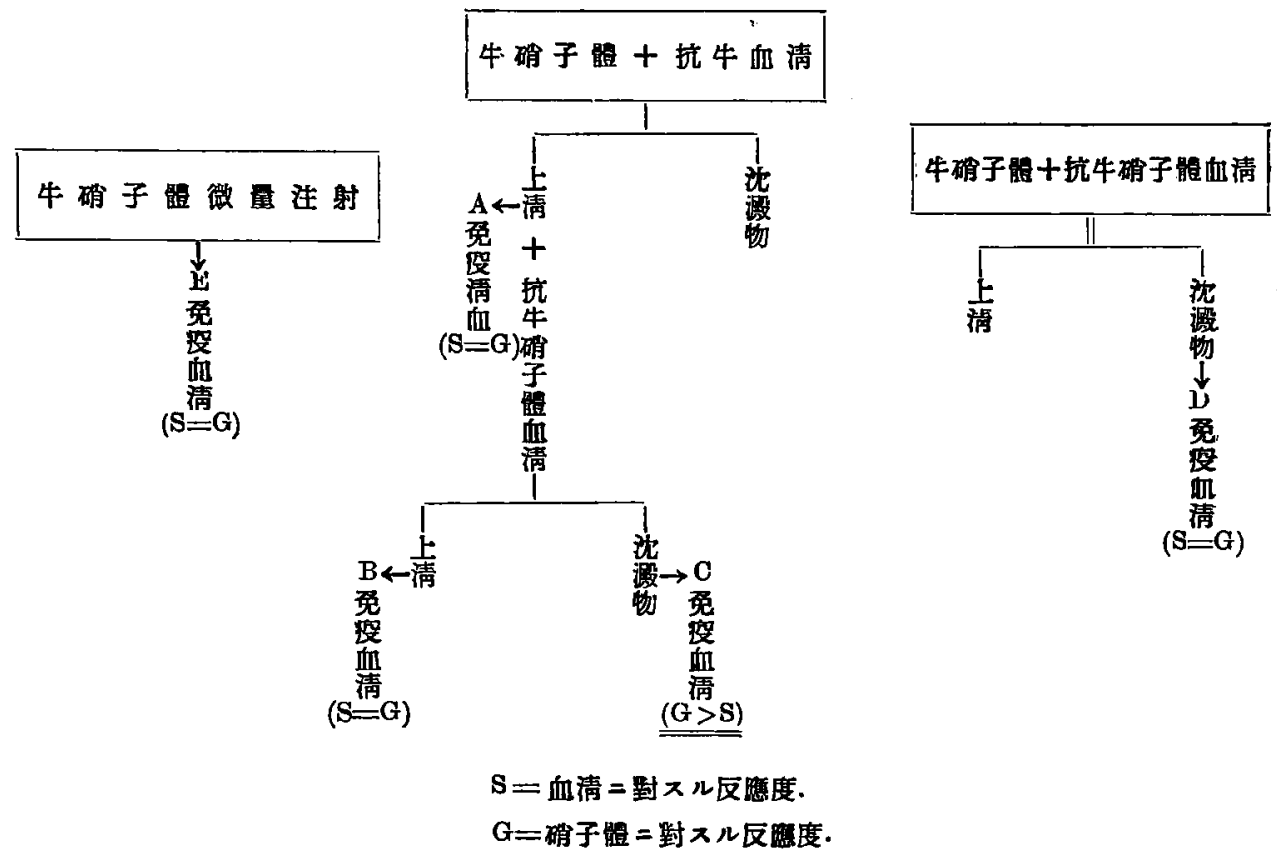

以上/方法ニヨリ得タル免度血清ノ各ネニシキ境明スレバ狄ノ如シ.

A. gruppe 㣻疫血清二就

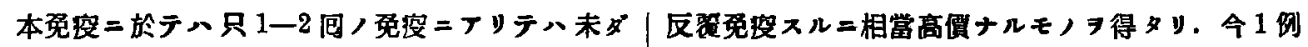
尚ホ沈降素，迹生

第 8 表 沈 降 反應 (Nr. 115 家鬼)

\begin{tabular}{|c|c|c|c|c|c|c|c|c|c|c|}
\hline 㧤 原 & 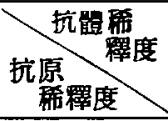 & $\begin{array}{l}- \\
\ddot{r} \\
\end{array}$ & $\begin{array}{l}0 \\
\ddot{\sim} \\
\ddot{\sim}\end{array}$ & $\begin{array}{l}8 \\
\ddot{-} \\
\end{array}$ & $\begin{array}{l}\text { ㅇ } \\
\ddot{-} \\
\end{array}$ & $\begin{array}{l}8 \\
\ddot{\sim} \\
\end{array}$ & \begin{tabular}{l}
8 \\
\hdashline \\
\hdashline \\
$ت$
\end{tabular} & $\begin{array}{l}\stackrel{8}{8} \\
\dddot{-} \\
- \\
\end{array}$ & \begin{tabular}{l}
8 \\
$\stackrel{9}{+}$ \\
\hdashline \\
\end{tabular} & $\begin{array}{l}8 \\
8 \\
\ddot{-} \\
- \\
\end{array}$ \\
\hline $\begin{array}{l}\text { 牛 } \\
\text { 硝 } \\
\text { 子 } \\
\text { 䯣 }\end{array}$ & $\begin{array}{lr}1: & 500 \\
1: & 1000 \\
1: & 2000 \\
1: & 4000 \\
1: & 8000 \\
1: & 16,000 \\
1: & 32,000 \\
1: & 64,000\end{array}$ & $\begin{array}{l}\text { 冊 } \\
\text { 無 } \\
\text { 無 } \\
\text { 冊 } \\
\text { H }\end{array}$ & $\begin{array}{l}\text { 冊 } \\
\text { 带 } \\
\text { 带 } \\
\text { 冊 } \\
\text { 朿 } \\
\text { - }\end{array}$ & 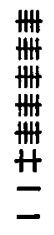 & $\begin{array}{l}\text { 冊 } \\
\text { 無 } \\
\text { 冊 } \\
\text { 巠 } \\
= \\
=\end{array}$ & $\begin{array}{l}\text { 册 } \\
\text { 带 } \\
\text { 制 } \\
\text { ㅍ } \\
=\end{array}$ & $\begin{array}{l}+ \\
+ \\
+ \\
+ \\
\text { H } \\
= \\
=\end{array}$ & $\begin{array}{l}\overline{+} \\
+ \\
+ \\
= \\
=\end{array}$ & $\begin{array}{l}\bar{z} \\
\bar{z} \\
\bar{z} \\
=\end{array}$ & $\begin{array}{l}= \\
\bar{z} \\
\bar{z}\end{array}$ \\
\hline 血 & $\begin{array}{lr}1: & 250 \\
1: & 500 \\
1: & 1000 \\
1: & 2000 \\
1: & 4000 \\
1: & 8000 \\
1: & 16,000 \\
1: & 32,000 \\
1: & 64,000\end{array}$ & 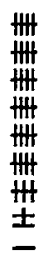 & $\begin{array}{l}\text { 册 } \\
\text { 带 } \\
\text { 無 } \\
\text { 冊 } \\
\text { H } \\
=\end{array}$ & $\begin{array}{l}\text { 冊 } \\
\text { 册 } \\
\text { 册 } \\
\text { 开 } \\
\text { I } \\
= \\
=\end{array}$ & $\begin{array}{l}\text { 生 } \\
\text { 無 } \\
\text { 型 } \\
+ \\
= \\
=\end{array}$ & $\begin{array}{l}\text { 册 } \\
\text { 册 } \\
\text { 册 } \\
= \\
= \\
=\end{array}$ & $\begin{array}{l}H \\
H \\
H \\
\# \\
\pm \\
= \\
=\end{array}$ & $\begin{array}{l}\bar{z} \\
\pm \\
\bar{z} \\
\bar{z}\end{array}$ & $\begin{array}{l}\bar{z} \\
\bar{z} \\
=\end{array}$ & $\begin{array}{l}\bar{z} \\
\bar{z} \\
\bar{z} \\
=\end{array}$ \\
\hline
\end{tabular}




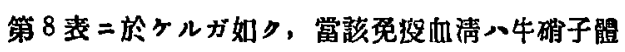
二對シ「U」氏法. $1: 32,000$ 希䆁法. 結合帶, $1: 2,000$

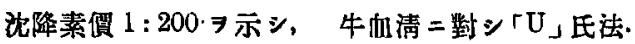

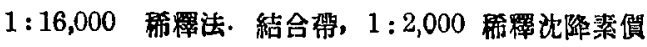
1: 200 э示ス.

牛硝子體ニ跱シテモ牛血清ニ歁シテモ常二同一結

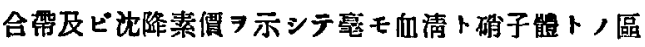

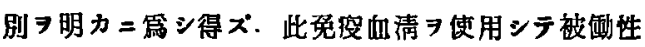

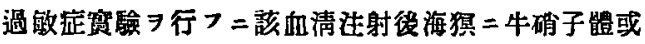
ヘ牛血清 $\nabla$ 再注射七几货醶成績八即千第 9 表二於テ
示をり.

余八第 8 表揭示，免没血清 7 䯤重 250-300g，健

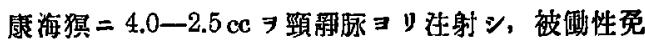

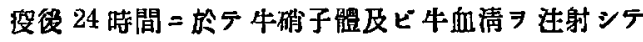
過敏定／有無习湓七り.

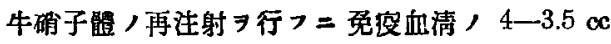
＼cjkstart注射セルモノ八明力二5分間以内 = Schocktod， 轉機 的定狀 7 表ハシタリ.

第 9 表被働性過敏应二於々ル筫驗

\begin{tabular}{|c|c|c|c|c|c|c|c|c|}
\hline 海 & 體 & 总 & 浸 & 血 & 清 & 潜 & 抗 & 過 \\
\hline $\begin{array}{l}\text { 猬 } \\
\text { 番 } \\
\text { 號 }\end{array}$ & $\begin{array}{c}\text { 重 } \\
\text { (g) }\end{array}$ & $\begin{array}{l}\text { ᄀ } \\
\stackrel{\text { L }}{\text { 祇 }}\end{array}$ & $\begin{array}{l}\text { 結 } \\
\text { 合 } \\
\text { 帶 }\end{array}$ & 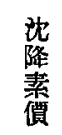 & $\begin{array}{l}\text { 感 } \\
\text { 作 } \\
\text { 量 }\end{array}$ & 伏 & $\begin{array}{l}\text { 宸 } \\
\text { 洼 } \\
\text { 射 } \\
\text { 畳 }\end{array}$ & $\begin{array}{l}\text { 敏 } \\
\text { 症 } \\
\text { 狀 }\end{array}$ \\
\hline
\end{tabular}

I. 牛硝子唯 $\Rightarrow$ 再注射七ル場合

\begin{tabular}{|c|c|c|c|c|c|c|c|c|}
\hline Nr. 1 & 300 & $1: 32000$ & $1: 2000$ & $1: 200$ & $4.0 \propto c$ & 24 時間 & $4.0 \mathrm{cc}$ & 死. $3^{\prime}$ \\
\hline Nr. 2 & 260 & $1: 32000$ & $1: 2000$ & $1: 200$ & $3.5 \mathrm{cc}$ & $"$ & $4.0 \mathrm{cc}$ & 死. $5^{\prime}$ \\
\hline Nr. 3 & 250 & $1: 32000$ & $1: 2000$ & $1: 200$ & $2.5 c$ & $\Rightarrow$ & $4.0 \propto c$ & 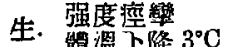 \\
\hline 封嬖 & 300 & / & / & 1 & 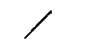 & $\ell$ & $4.0 \mathrm{cc}$ & 生. 症状ナシ \\
\hline
\end{tabular}

II. 牛血清 $\boldsymbol{7}$ 再注射セル場合

\begin{tabular}{|c|c|c|c|c|c|c|c|c|}
\hline Nr. 4 & 270 & $1: 16000$ & $1: 2000$ & $1: 200$ & $4.0 \mathrm{cc}$ & 24時間 & $0.02 \mathrm{cc}$ & 死. $5^{\prime}$ \\
\hline Nr. 5 & 265 & $1: 16000$ & $1: 2000$ & $1: 200$ & $3.5 \propto$ & $"$ & $0.01 \mathrm{cc}$ & 死. $5^{\prime}$ \\
\hline Nr. 6 & 250 & $1: 16000$ & $1: 2000$ & $1: 200$ & $2.5 c c$ & $"$ & $0.01 \mathrm{cc}$ & 生. 强度過敏症 \\
\hline 對照 & 260 & ノ & 1 & 1 & 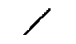 & I & $0.02 \mathrm{cc}$ & 生. 症狀ナシ \\
\hline
\end{tabular}

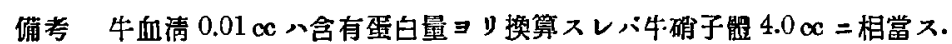

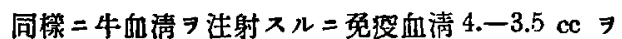

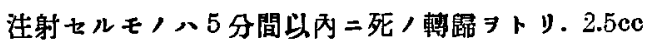

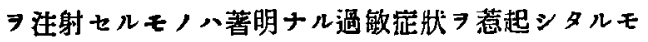

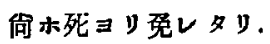

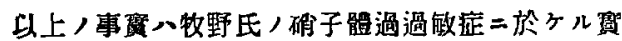

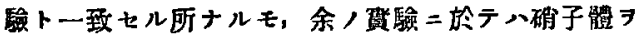
再注射セ儿場合ガ舟清抗原 $尹$ 再泩射スル場合ヨリモ 稍に其ノ定狀著明ナルガ如ク思ハレタリ．郎于第 9 表ニテ示スガ如キ成績ナリ。
要之二A. gruppe 免溫血清二於テハ沈降反照モ俩 敏定反照二於テモ共二牛碳子䯣卜血清抗原，明確ナ 儿區別困難ナルモノナリ。故二以上ノ方法ニヨリ炭 没セラレタル家鬼，免投血清八毫モ湔足スへキ特異 性抗硝子體血清トN云ヒ踓クシテ, 是レ恐ラクハ抗 血清要疫向清 7 以テシテハ确子體中，含有向清共通

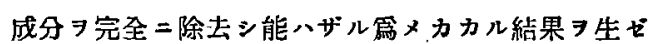
シモノナルデシ. 
B. gruppe 免疫血清二就テ

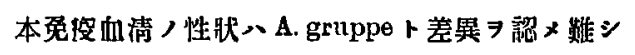
的千牛确子能站二血清二對シ共二著明ナル反㮣 シ而モ其，反隹度二於テ彼我，區剧困難ナリ。

過敏症反㮣二於テモA. gruppe，埸合卜異儿所ナ キヨ以テ特ニ表习省略スルコトトセリ。

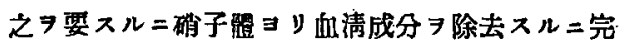
全习期シ雖キ篇入，此Abgnss =5免设シテ得 ル 家鬼，免投血清八硝子體卜血清卜，反鹤度同一ナル

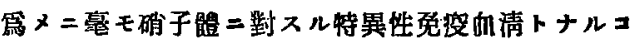
ト能ハズ.

\section{C. gruppe 免疫血清二就テ}

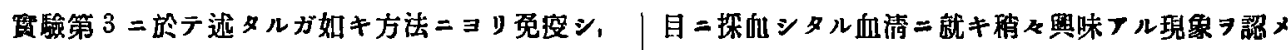

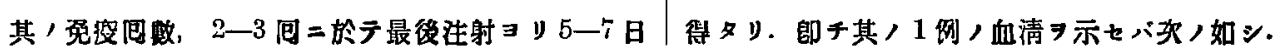

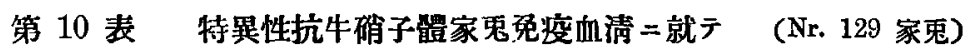

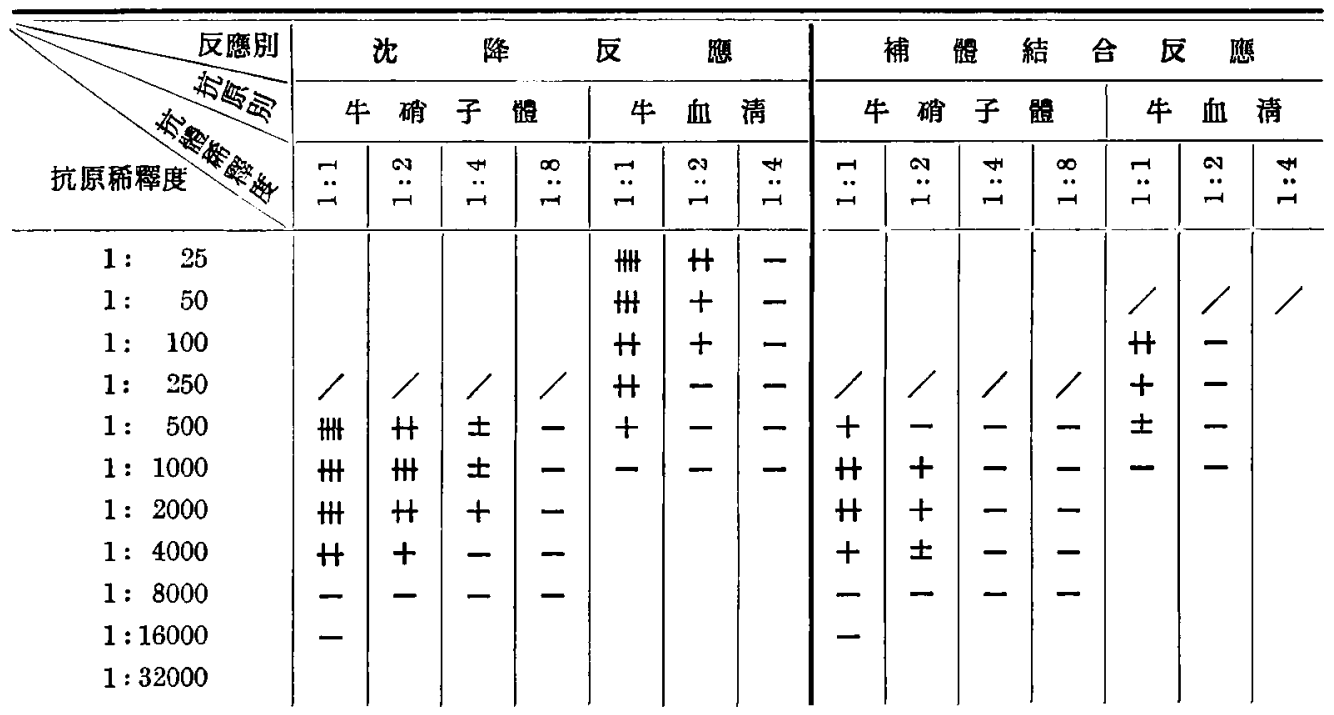

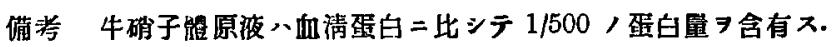

第 10 表二於テ示スガ如ク，沈降反㮣

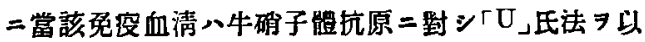
テスル $=1: 4,000$ 迄反楒シ得, 而シテ其 稀释沈降 素㵋ハ4 倍ナリ.反之，牛血清ニ對シテハ500倍，

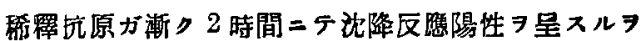

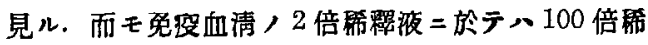
稺抗原二於テ始×テ，陽性反應 7 呈

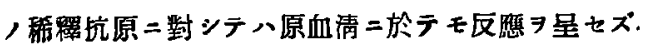

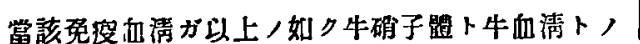

間二從來少ジ䜀メ得ザリシ著明ナル差異习現ス反

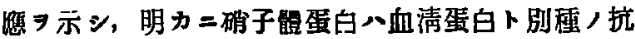
原ナルコトヨ證明シ得タルモノト信ズ.

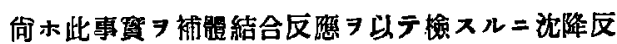
應二於ヶルガ如ク著明ナル差異 7 認

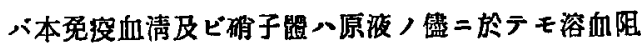

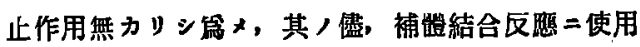
セり.

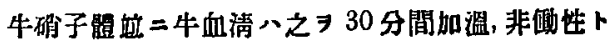


篇シテ，之ヨ抗原トシテ用七，硝子得八其，焦，血 清八100倍ヨリ䌮䁺シテ使用七り.

第 10 表 = 於テ 示スガ如ク，牛血清、500 倍抗原 稀䆁度二於テ僅ニ(士)ナル反隹ナルニ牛硝子體八

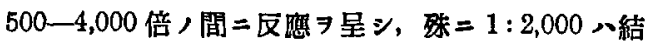
合带ニシテ 2 倍，免度血清卜著明二反虑

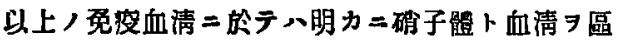

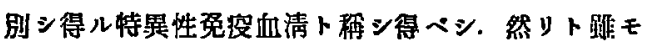

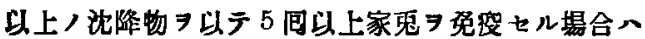
全然之ヨ除去シ能・ザ儿抗原性/强キ血清成分，臨 メ二厴倒サレテ，以上，如キ特異ナル反應 $\ni$ 呈セザ

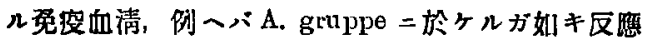
ヨ現スニ至レリ.

之尹要スル 除外スル事、不可能ナル 7 以テ, 免疫回數 7 增ス 從テ，ヤガテ血清二到スル抗體／多箸二產生シ來り テ，之ト區刷困蜼トナルモノナラン.

余八筒ホ特異性硝子體蛋白，證明トシテ惹起シ易

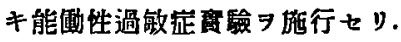

筫龭方法八，筫驗第 $3=\Xi$ リテ示セルガ如キ方法

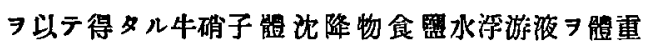
$250 \mathrm{~g}$ 內外／海猉／皮下又八腹腔內二注射シテ，之 二スル能働性過敏性 7 附與セシメテ後 10-14日 ，後二牛硝子體及ビ牛血清

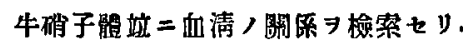

實驗動物トシテ最モ過敏症狀ヨ惹起シ易キモノト

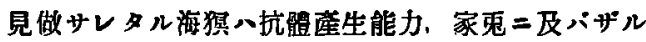

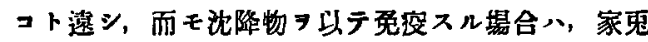
二於テスラ抗骴童生量多カラズ，況ヤ海㩧二於テ珠 二然 》，從ッテ到底定型的ノ過敏症狀 Schock 7 惹起 シ得ザルハ明カナル所ニシテ，余ハ之ガ篇メまトシ テ Mit几, Pfeiffer 氏賽驗ニョり過敏定ト密接ナル關

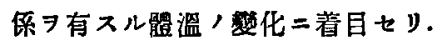

當該察驗海猽八再注射前二其ノ血清

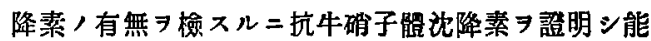
ハザル時二モ抗原，再过射 $=ヨ$ リテ過敏症狀 7 惹起 シ得儿事貾八白现 ${ }^{29}$ 氏等，報告スル所ナレドモ余， 場合一之等卜暴り，抗原ノ結合带 7 知ルニ由ナク， 從テ適當ナル再注射㢆 7 測定シ能ハザルナリ. 故 $=$

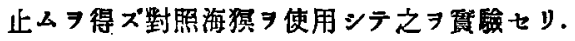

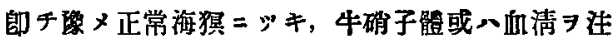

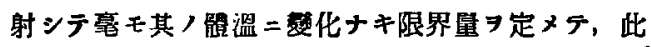
量以下

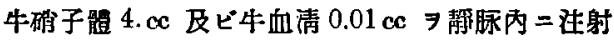

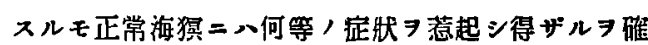

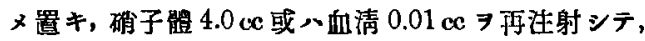

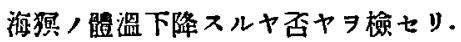

其，結果ハ第 11 表 $=$ 於ヶルガ如キ成縝 $尹$ 得 タリ。

第 11 表 牛硝子體沈降物

\begin{tabular}{|c|c|c|c|c|c|c|c|c|}
\hline \multirow{2}{*}{$\begin{array}{l}\text { 海 } \\
\text { 䁚 } \\
\text { 番 } \\
\text { 號 }\end{array}$} & \multirow{2}{*}{$\begin{array}{l}\text { 麗 } \\
\text { 䨒 } \\
(\mathrm{g})\end{array}$} & \multirow{2}{*}{ 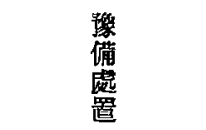 } & \multicolumn{3}{|c|}{ 海㺍血淸，沈降素二就テ } & \multirow{2}{*}{$\begin{array}{l}\text { 替 } \\
\text { 獄 } \\
\text { 期 } \\
\text { (日) }\end{array}$} & \multirow{2}{*}{$\begin{array}{l}\text { 再㧤 } \\
\text { 生原 } \\
\text { 射黨 } \\
\text { (c) }\end{array}$} & \multirow{2}{*}{$\begin{array}{l}\text { 過 } \\
\text { 敏 } \\
\text { 窄 } \\
\text { 狀 }\end{array}$} \\
\hline & & & 「ウ」氏法 & 結合帶 & 沈降素價 & & & \\
\hline \multicolumn{9}{|c|}{ 1. 牛硝子能抗原，再这射 } \\
\hline Nr. 1 & 250 & 牛硝子顝 $15 \mathrm{cc}$ ヨ & 0 & 0 & 0 & 14 & $4.0 \mathrm{cc}$ & $H$ \\
\hline Nr. 2 & 260 & , & 0 & 0 & 0 & 10 & 4.0 & - \\
\hline Nr. 3 & 240 & $\Rightarrow$ & 0 & 0 & 0 & 12 & 4.0 & + \\
\hline Nr. 4 & 255 & $"$ & 0 & 0 & 0 & 10 & 4.0 & + \\
\hline Nr. 5 & 260 & 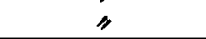 & 0 & 0 & 0 & 14 & 4.0 & I \\
\hline \multicolumn{9}{|c|}{ I. 牛血清抗原/再注射 } \\
\hline Nr. 6 & $\overline{230}$ & $"$ & 0 & 0 & $\frac{21}{0}$ & 14 & 0.01 & - \\
\hline & 240 & 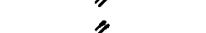 & 0 & 0 & 0 & 10 & 0.01 & - \\
\hline Nr. 8 & 260 & $"$ & 0 & 0 & 0 & 12 & 0.01 & - \\
\hline Nr. 9 & 250 & $"$ & 0 & 0 & 0 & 10 & 0.01 & - \\
\hline Nr. 10 & 255 & 4 & 0 & 0 & 0 & 14 & 0.01 & - \\
\hline
\end{tabular}


牛㗂子體沈降物

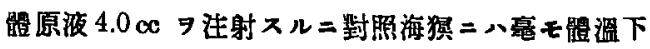

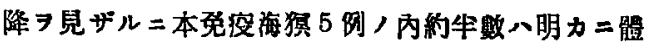

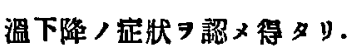

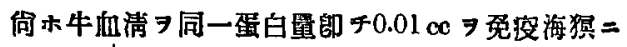

再注射スルモ 5 侧共何等，定狀ヨ惹起シ得ザリキ。

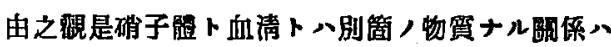
過敏定反應

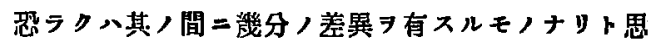
惟スベキモノナり.

D. gruppe 免役血清二就テ

本瓜度血清八0. gruppe 免没血清，對照睘驗，如 キモノナリ，即チ硝子能ヨリ血清成分

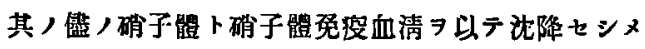

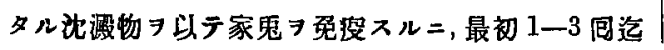

，免受二於テハ沈降素㵋多カラズ.

而モ得タル免疫血清モ硝子福㕸二血清抗原二對シ テ主副反輓 $\boldsymbol{7}$ 區刷シ得ズ。

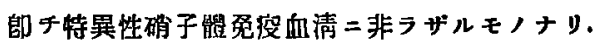

E. gruppe 鹰疫血清二就テ

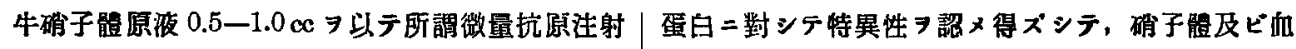

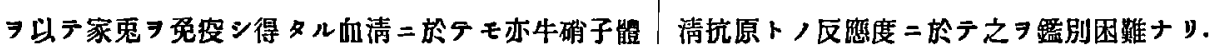

\section{第 6 章 總 括 考}

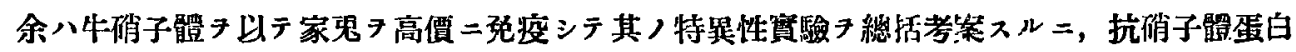

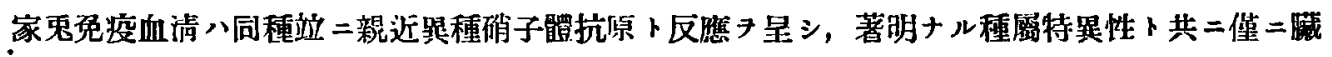

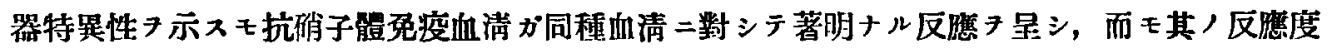
八硝子體抗湶二シテモ，血清抗原二對シテモ殆ド同ーナル結合帶及ピ反應度キ有スルキ以テ 果シテ硝子體二八血清成分ノミナルヤ, 又八硝子顝蛋白，固有ナルモノノ存在スルヤ不明ナり,

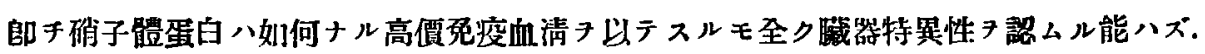

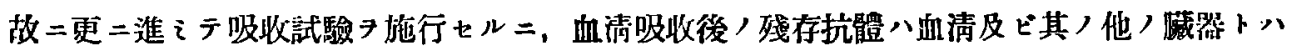

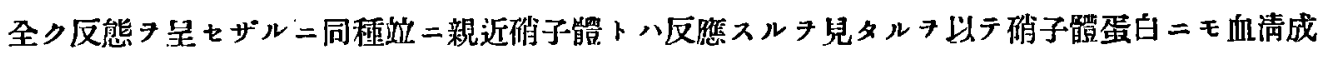

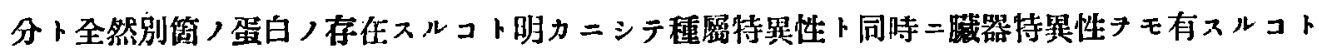

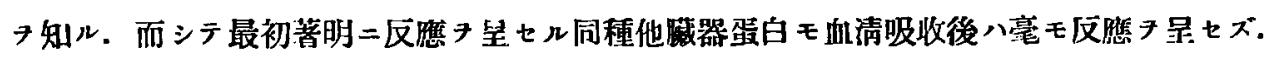

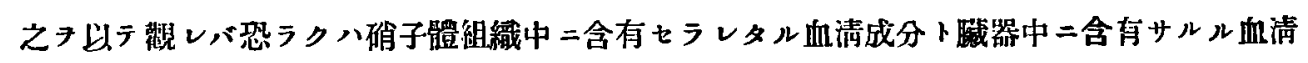

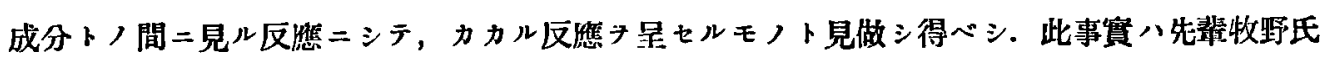
ノ所見トー致スル所ナリ。

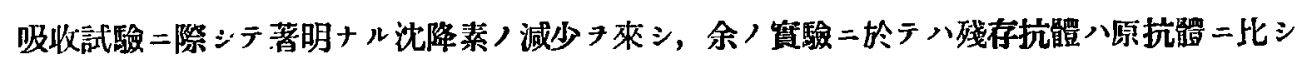
テ1/4-1/10トナルハ硝子體中二血清成分テ多量二包念サルルキ證明スルモノナリ。

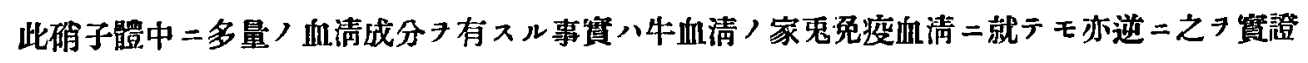
セラル。

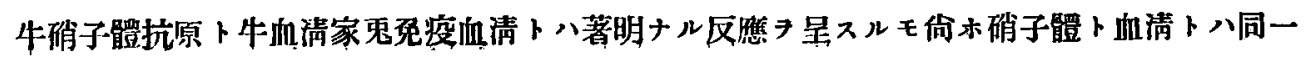


ナルモノニ非ラザルコトモ明カニスルタ得タリ.

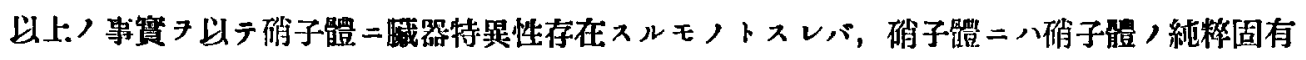
蛋白ノ存在き是鿁七ザルベカラス。

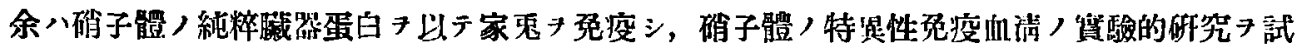

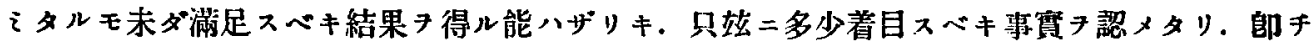

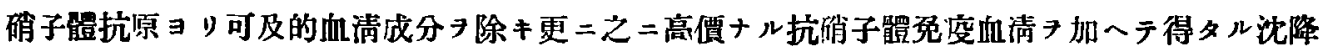

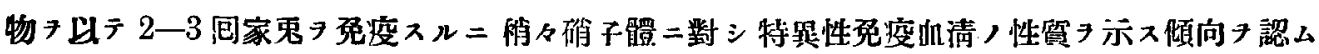
ベキ血清タ得タリ.

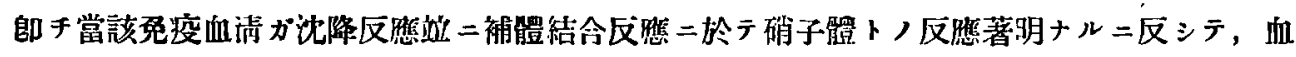
清ニ對シテ稍々弱シ。

併シ之ハ雨後免度回數，坦加卜共二此特暴性八娜次消失シテ，血清卜碓子體卜，區別モ亦困 難トナル。

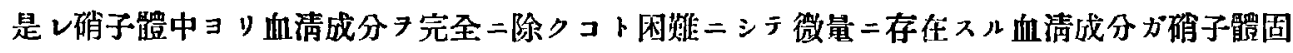

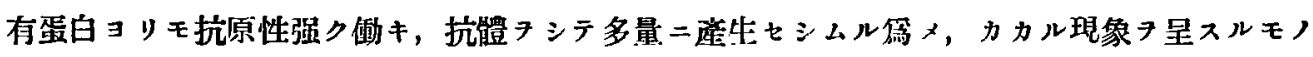
ナラン.

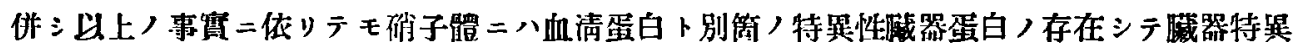
性タ有スル事筫フ被メ得タッ。

\section{第 7 章 結 論}

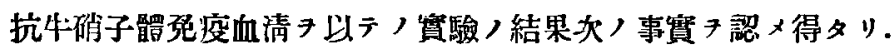

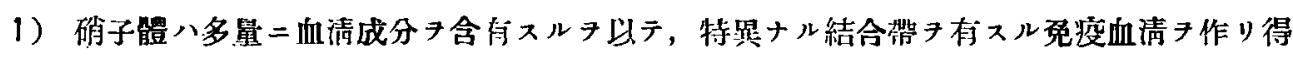

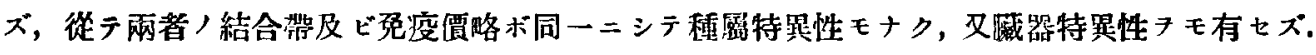

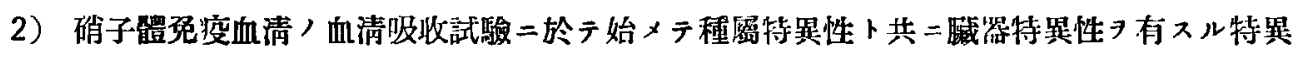
蛋白抗體? 存在丹知ル。

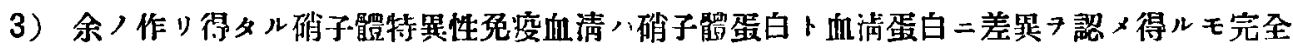
ナル非血清的免疫血清ナラズ.

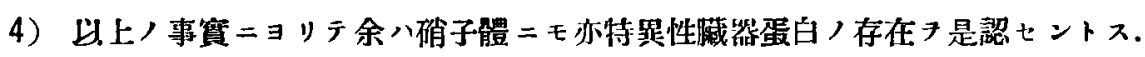

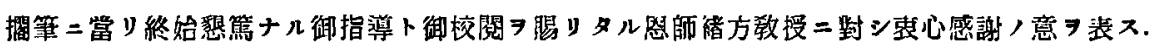




\section{文獻}

1) Rigobert Possek, Klin. Monntbl. f. Angenb., Ba. 45, S. 329, 1907. 2) Anatol Trubin, Arohiv f. Ophth., Bd. 89, S. 227, 1915. 3) Tribin, Arohiv f. Augenh, Bd. 77, s. 48, 1914. 4) Uhlenhath u. Haendel, Zeitsohr. f. Immnnititsf., Bd. 4, S. 761, 1910 . 5) Römer $u$. Gebb, Grefes Arohiv f. Ophtb., Bd. 81, s 367, 1912. 6) Uhlenhuth, Deut. med. Wochenschr., Nr. 31, S. $1245,1906 . \quad 7)$ S. Mita, Zeitschr. f. Immunitätsf., Bd. 5, 8. 1910. 8) Pfeiffer \%. Mita, Ebendn, Bd. 4, S. 410，1910. 9) 中村，河本教授视賀論文集，221 頁，大正 8 年. 10）村上，日

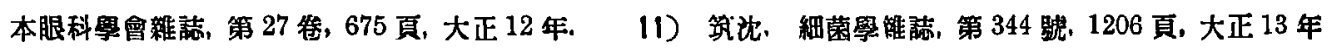

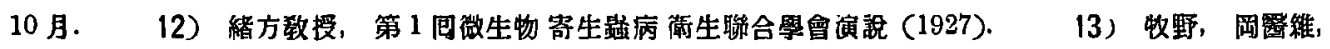

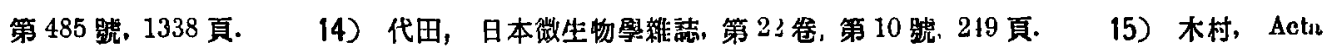
Scholne medicinalis universitatis in Kiuto, Vol. VIII, Fusc. 3, S. 309-321, 1925. 16) 白㺵, 日眼雑,

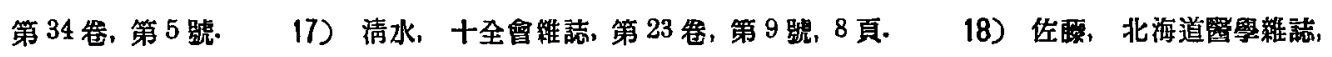

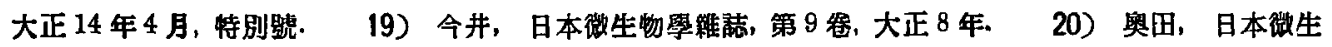

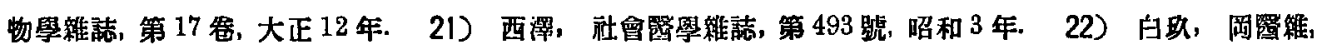
第 485 號, 1372 頁, 1930. 